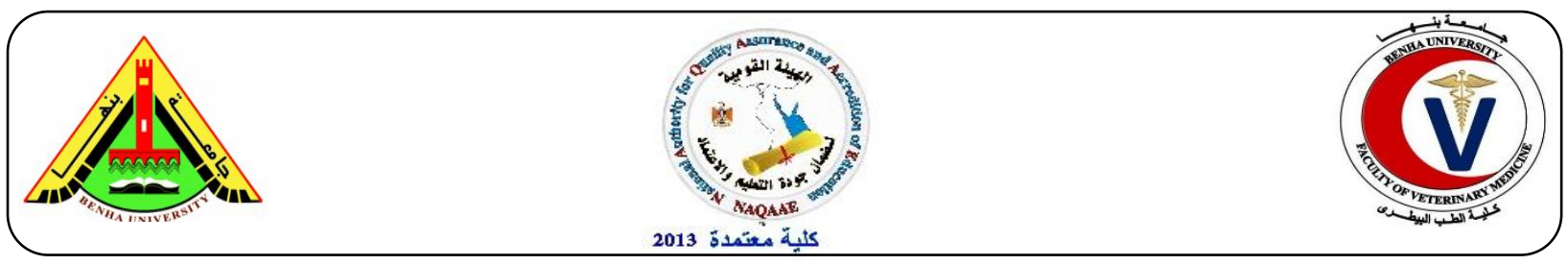

\title{
Incidence of some anaerobic bacteria isolated from chicken meat products with special reference to Clostridium perfringens
}

Shaltout, F. A. ${ }^{1}$; Zakaria, I. M. ${ }^{2}$; Nabil, M.E. ${ }^{3 .}$

${ }^{1}$ Food hygiene Dept., Faculty of Veterinary Medicine, Benha University; ${ }^{2}$ Animal Health Research Institute (El-Dokki - Bacteriology Dept.); ${ }^{3}$ Animal Health Research Institute (Benha Branch - Food Control Dept.)

\section{A B S T R A C T}

Anaerobic spore formers, especially Clostridium perfringens, represent one of the most prevalent bacterial food poisoning outbreaks which mostly related to consumption of contaminated meat and meat products, therefore, a total of 125 random raw and half cooked chicken meat samples represented by (breast, thigh, nuggets, panée and frankfurter "25 of each") were collected from various retail stores and supermarkets in Qualyubia governorate. Results illustrated that, raw thigh samples were the most contaminated with anaerobic bacterial counts in incidence of $84 \%$. The identified strains were $C$. perfringens, C. sporogenes, C. bifermenants, C. butyricum and C. sordelli in 21.6, 16, 8, 3.2 and 3.2\%, respectively. Regarding to the incidence of vegetative and spore of $C$. perfringens were 24, 32, 20, 16, $16 \%$ and 16, 20, 16, 8, 8\% in examined raw breast, raw thigh, nuggets, panée and frankfurter, respectively. 33.3\% of isolates were lecithinase positive strains and typed as C. perfringens type A (6.4\%), type D $(0.8 \%)$; in absence of neither type B nor D. Experimental heat resistant $C$. perfringens spores were six heat resistant strains; where all isolates were of type A. The high incidence of these food poisoning microorganisms in chicken meat may indicate defects in sanitary conditions and handling in processing plant.

Keywords: chicken meat, Clostridium perfringens, heat resistant spores, Nagler's reaction, other anaerobes.

\section{INTRODUCTION}

Rapid reproductive cycle, high acceptability of poultry meat due to its high biological value, palatability and many production processing variables; made poultry production one of the major worldwide food industry. Selection of broiler chickens has been primarily directed at economic traits which have reduced costs of production.

In Egypt, Chicken represents the major brand of production and consumption among poultry. Chicken meat becomes the most popular meat eaten due to its reliable price, health benefits and good flavor. Chicken meat is easily prepared, consistent quality and wide ranged pre-packed, raw and ready to eat products (Shedeed, 1999).

Poultry and poultry products are subjected to contamination with several types of microorganisms from different sources from the time of rearing, slaughtering till consumption. Such contamination may render the product inferior quality or even contributed in public health hazards. 
Any defect of the hygienic measures in the slaughtering houses and/or processing plants leads to microbial contaminations, which cause serious diseases for the consumer. Thus, raw poultry products are reported to be responsible for a significant number of cases of human food poisoning (Geornaras et al., 1995).

In processing plants, contamination of poultry meat products may be recorded throughout initial processing, packaging and storage until the product is sufficiently cooked and consumed. Heavy bacterial loads enter the processing operations with the living birds or raw materials can be disseminated throughout the plant during processing. Food poisoning may occur when these products not properly cooked or due to post-processing contamination (Zhang et al., 2001).

Regarding to slaughtering abattoirs and processing plants hygiene, the presence of pathogenic and spoilage microorganisms in poultry meat and its products represent a significant concern for suppliers, consumers and public health officials worldwide. Bacterial contamination of food products is undesirable but unavoidable; it depends on the initial bacterial load of the fresh raw materials, hygienic practices during manufacturing and on time/temperature factor (El-Bassuony, 2008).

Foodborne infection and intoxication outbreaks are increasing especially in industrial and developing countries, where bacterial foodborne infection is the major reported cases (Stevenson and Bernard, 1995); where anaerobic spore formers bacteria are considered as one of the causative agents of poultry meat borne infection. Clostridia have been incriminated in many anaerobic infections by producing toxins that are able to damage tissues of the nervous system as well as lead to inflammation and even destroy the wall of the large and small intestine, this condition is called necrotizing enterirtis, this infection may be occurred as an isolated case or may be considered as outbreaks caused by consumption of contaminated meat (Varnam and Evans, 1991).

C. perfringens is a ubiquitous pathogen and natural intestinal inhabitant of poultry, different stages of poultry processing line can add a contamination source even starting from the hatchery. Chicken carcass and meat cuts may also be contaminated with $C$. perfringens from intestinal contents during slaughterhouse process especially during evisceration (Voidarou et al., 2011).

Moreover, $C$. perfringens is a common foodborne pathogen associated with food poisoning, gas gangrene, and infectious diarrhea in human. Because of its ability to form a spore, this microorganism is able to survive adverse conditions such as aerobic and food processing procedures. $C$. perfringens causes food poisoning postingestion, because a large number of vegetative cells can survive acidic $\mathrm{pH}$ of the stomach, then sporulate and produce an enterotoxin in the small intestine (Santos et al., 2002).

Therefore, the current study was plamed for monitoring of anaerobic spore formers especially $C$. perfringens in raw and half cooked chicken meat products.

\section{MATERIAL AND METHODS}

\subsection{Collection of samples:}

A total of 125 random samples of fresh raw and partially cooked chicken meat products represented by chicken breast, chicken thigh, chicken nuggets, chicken panée and chicken frankfurter (25 of each), these were collected from different retail groceries and supermarkets in Qalyubiya governorate 
Incidence of some anaerobic bacteria isolated from chicken meat products with special reference to Clostridium perfringens

for bacteriological examination. All the collected samples were subjected to the following examination.

2.2. Preparation of the samples: 1992)

It was done according to (APHA,

2.3. Determination of total anaerobic bacterial count:

It was done according to (Roberts et al., 1995) using reinforced clostridial agar media.

2.4. Determination of viable Clostridium perfringens:

It was done according to (ISO, 2004) using TSC media.

\subsection{Determination of Clostridium perfringens spores:}

It was done according to (Weiss and Strong, 1967) using Clostridium perfringens agar plate media.

2.6. Isolation of Clostridium perfringens:

It was done according to (Carter and Cole, 1990) using cooked meat media and $10 \%$ sheep blood agar.

\subsection{Identification of Clostridium} perfringens:

It was done according to (MacFaddine, 1980 and Cato et al. 1986).

\subsubsection{Staining:}

It was done according to (Cruickshank et al., 1975).

\subsubsection{Cultural characteristics:}

It was done according to (Cruickshank et al., 1975):

2.7.2.1. Cooked meat media.

2.7.2.2. Sheep blood agar media.

2.7.2.3. Egg yolk agar media (Nagler's reaction).

\subsubsection{Nutrient gelatin media.}

2.7.3. Biochemical reactions.

2.7.3.1. Nitrate reduction test:

It was done according to (Willis, 1977).

2.7.3.2. Zinc Test:

2.7.3.3. Indole production test:

It was done according to (MacFaddine, 1980)

2.7.3.4. Hydrogen sulphid test:

It was done according to (MacFaddine, 1980).

\subsubsection{Sugar fermentation test;}

It was done according to (Willis, 1977).

2.7.4. Neutralization test in Swiss mice:

It was done according to (Smith and Holdeman, 1968).

2.7.5. Determination of $C$. perfringens toxin by dermonecrotic test:

It was done according to (Sterne and Batty, 1975).

2.7.5.1.Preparation of toxin and their treatment:

It was done according to (Bullen, 1952).

2.7.5.2. Application of the typing test:

It was done according to (Oakley and Warrack, 1953): the results were interperitated by the degree of dermonecrotic reaction and its neutralization according to Sterne and Batty (1975).

2.8. Detection of $C$. perfringens heat resistant spores:

2.8.1. Preparation of $C$. perfringens spore suspension: 
It was done according to (Ellner, 1956).

2.8.2. Determination of heat spore resistance:

It was done according to (Hussein, 1997).

\subsection{Statistical analysis:}

The obtained results were statistically evaluated by application of Analysis of Variance (ANOVA) test according to Feldman et al. (2003).

\section{RESULTS}

Results as tabulated in table (1) revealed that examined raw thigh samples were the most contaminated with anaerobic bacterial count in prevalence of $84 \%$, followed by breast, nuggets, panée and frankfurter in 76,48 , 48 and $40 \%$, respectively.

Also, results demonstrated in table (2) showed the incidence of isolation and identification of anaerobic isolates revealed detection of $\mathrm{C}$. perfringens, C. sporogenes, C. bifermenants, C. butyricum and C. sordelli in 21.6, 16, 8, 3.2 and $3.2 \%$ of examined samples, respectively.

As shown in table (3) results illustrated that the incidence of vegetative form $C$. perfringens were 24 , $32,20,16$ and 16\%; while in table (4) that in spore form C. perfringens was $16,20,16,8$ and $8 \%$ in examined raw breast, raw thigh, nuggets, panée and frankfurter samples, respectively. From these isolates $33.3 \%$ were lecithinase positive strains as recorded in table (5). There were significant differences between breast and thigh as raw samples; and between raw examined samples and half cooked samples. In reference to (EOS, 2005); 20 and $24 \%$ of examined nuggets and panée samples were rejected those were exceeding the permissible limits of total anaerobic counts. $8,28,20,16$ and $16 \%$ of examined breast, thigh, nuggets, panée and frankfurter were rejected for C. perfringens cell counts.

Typing of toxigenic C. perfringens isolates results were recorded in table (6) proved C. perfringens type A in incidence of $6.4 \%$ followed by type $\mathrm{D}$ in incidence of $0.8 \%$; in absence of neither type $\mathrm{B}$ nor $\mathrm{D}$ basing on classical bioassay.

Regarding to detection of heat resistant spores of C. perfringens isolated, results showed in table (7) revealed that six heat resistant strains were detected in prevalence of $4.8 \%$; where all isolates were classified as type A. 
Incidence of some anaerobic bacteria isolated from chicken meat products with special reference to Clostridium perfringens

Table (1) total anaerobic count/g of the examined chicken meat product samples $(n=25)$.

\begin{tabular}{|c|c|c|c|c|c|c|c|c|}
\hline \multirow{3}{*}{ Sample } & \multirow{2}{*}{\multicolumn{2}{|c|}{$\begin{array}{l}\text { Positive } \\
\text { samples }\end{array}$}} & \multicolumn{3}{|c|}{ Count of $\mathrm{cfu} / \mathrm{g}$} & \multirow{3}{*}{$\begin{array}{l}N \\
8 \\
\end{array}$} & \multirow{2}{*}{\multicolumn{2}{|c|}{$\begin{array}{l}\text { Rejected } \\
\text { samples }\end{array}$}} \\
\hline & & & \multirow{2}{*}{ Min. } & \multirow{2}{*}{ Max. } & \multirow{2}{*}{ Mean $\pm \mathrm{SE}^{*}$} & & & \\
\hline & NO. & $\%$ & & & & & No. & $\%$ \\
\hline \multicolumn{9}{|c|}{ Raw chicken meat } \\
\hline $\begin{array}{c}\text { Chicken } \\
\text { breast }\end{array}$ & 19 & 76 & $1.4 \times 10^{3}$ & $2.3 \times 10^{4}$ & $1.05 \times 10^{4} \pm 1.4 \times 10^{3 \mathrm{~b}}$ & - & - & - \\
\hline $\begin{array}{l}\text { Chicken } \\
\text { thigh }\end{array}$ & 21 & 84 & $2.5 \times 10^{3}$ & $6.8 \times 10^{4}$ & $2.8 \times 10^{4} \pm 4.0 \times 10^{3 \mathrm{a}}$ & - & - & - \\
\hline \multicolumn{9}{|c|}{ Half cooked chicken meat products } \\
\hline $\begin{array}{l}\text { Chicken } \\
\text { nuggets }\end{array}$ & 12 & 48 & $1.5 \times 10^{2}$ & $1.8 \times 10^{3}$ & $8.4 \times 10^{2} \pm 9.2 \times 10^{c}$ & $10^{2}$ & 5 & 20 \\
\hline $\begin{array}{l}\text { Chicken } \\
\text { panée }\end{array}$ & 12 & 48 & $1.6 \times 10^{2}$ & $1.4 \times 10^{3}$ & $6.8 \times 10^{2} \pm 7.0 \times 10^{c}$ & $10^{2}$ & 6 & 24 \\
\hline $\begin{array}{l}\text { Chicken } \\
\text { frankfurter }\end{array}$ & 10 & 40 & $2.0 \times 10^{2}$ & $9.8 \times 10^{2}$ & $5.3 \times 10^{2} \pm 4.9 \times 10^{c}$ & $10^{2}$ & 0 & 0 \\
\hline Total & 74 & 59.2 & - & - & - & - & 11 & 8.8 \\
\hline
\end{tabular}

Table (2): Incidence of anaerobic spore former other than Clostridium perfringens in examined chicken meat products $(\mathrm{n}=25)$.

\begin{tabular}{|c|c|c|c|c|c|c|c|c|}
\hline \multirow{2}{*}{ Samples } & \multicolumn{2}{|c|}{ C. sporogenes } & \multicolumn{2}{|c|}{ C. bifermenants } & \multicolumn{2}{|c|}{ C. butyricum } & \multicolumn{2}{|c|}{ C. sordelli } \\
\hline & No. & $\%$ & No. & $\%$ & No. & $\%$ & No. & $\%$ \\
\hline \multicolumn{9}{|c|}{ Raw chicken meat } \\
\hline Chicken breast & 3 & 12 & 2 & 8 & 1 & 4 & 0 & 0 \\
\hline Chicken thigh & 5 & 20 & 4 & 16 & 2 & 8 & 1 & 4 \\
\hline \multicolumn{9}{|c|}{ Ready to cook } \\
\hline Chicken nugget & 5 & 20 & 1 & 4 & 0 & 0 & 1 & 4 \\
\hline Chicken pane & 4 & 16 & 2 & 8 & 0 & 0 & 2 & 8 \\
\hline Chicken frankfurter & 3 & 12 & 1 & 4 & 1 & 4 & 0 & 0 \\
\hline Total & 20 & 16 & 10 & 8 & 4 & 3.2 & 4 & 3.2 \\
\hline
\end{tabular}


Table (3): Statistical analysis of Clostridium perfringens (vegetative form) count/g of the examined chicken meat product samples $(n=25)$.

\begin{tabular}{|c|c|c|c|c|c|c|c|c|}
\hline \multirow[t]{2}{*}{ Samples } & \multicolumn{2}{|c|}{$\begin{array}{l}\text { Positive } \\
\text { samples }\end{array}$} & \multicolumn{3}{|c|}{ Count of $\mathrm{cfu} / \mathrm{g}$} & \multirow{2}{*}{$\begin{array}{l}N \\
\delta \\
\end{array}$} & \multicolumn{2}{|c|}{$\begin{array}{c}\text { Rejected } \\
\text { samples }\end{array}$} \\
\hline & NO. & $\%$ & Min. & Max. & Mean \pm SE* & & No. & $\%$ \\
\hline \multicolumn{9}{|c|}{ Raw chicken meat } \\
\hline $\begin{array}{c}\text { Chicken } \\
\text { breast }\end{array}$ & 6 & 24 & $5.2 \times 10^{2}$ & $2.07 \times 10^{4}$ & $9.1 \times 10^{3} \pm 2.7 \times 10^{3 \mathrm{~b}}$ & $10^{3}$ & 2 & 8 \\
\hline $\begin{array}{c}\text { Chicken } \\
\text { thigh }\end{array}$ & 8 & 32 & $1.2 \times 10^{3}$ & $5.03 \times 10^{4}$ & $2.5 \times 10^{4} \pm 5.7 \times 10^{3 \mathrm{a}}$ & $10^{3}$ & 7 & 28 \\
\hline \multicolumn{9}{|c|}{ Half cooked chicken meat products } \\
\hline $\begin{array}{l}\text { Chicken } \\
\text { nuggets }\end{array}$ & 5 & 20 & $2.4 \times 10^{2}$ & $1.2 \times 10^{3}$ & $5.6 \times 10^{2} \pm 1.7 \times 10^{2 \mathrm{ab}}$ & Free & 5 & 20 \\
\hline $\begin{array}{l}\text { Chicken } \\
\text { panée }\end{array}$ & 4 & 16 & $1.9 \times 10^{2}$ & $1.1 \times 10^{3}$ & $6.9 \times 10^{2} \pm 2 \times 10^{2 \mathrm{ab}}$ & Free & 4 & 16 \\
\hline $\begin{array}{l}\text { Chicken } \\
\text { frankfurter }\end{array}$ & 4 & 16 & $9 \times 10$ & $7.5 \times 10^{2}$ & $4.1 \times 10^{2} \pm 1.4 \times 10^{2 \mathrm{ab}}$ & Free & 4 & 16 \\
\hline Total & 27 & 21.6 & - & - & - & - & 22 & 17.6 \\
\hline
\end{tabular}

Table (4): Statistical analysis of Clostridium perfringens (spore form) count/g of the examined chicken meat product samples $(\mathrm{n}=25)$.

\begin{tabular}{|c|c|c|c|c|c|}
\hline \multirow{2}{*}{ Samples } & \multicolumn{2}{|c|}{ Positive samples } & \multicolumn{3}{|c|}{ Count of cfu/g } \\
\hline & NO. & $\%$ & Min. & Max. & Mean \pm SE. \\
\hline \multicolumn{6}{|c|}{ Raw chicken meat } \\
\hline Chicken breast & 4 & 16 & $1.2 \times 10^{2}$ & $2.2 \times 10^{3}$ & $9.7 \times 10^{2} \pm 4.4 \times 10^{2}$ \\
\hline Chicken thigh & 5 & 20 & $1 \times 10^{2}$ & $1.9 \times 10^{3}$ & $8.4 \times 10^{2} \pm 3 \times 10^{2}$ \\
\hline \multicolumn{6}{|c|}{ Half cooked chicken meat products } \\
\hline Chicken nuggets & 3 & 16 & $3.2 \times 10$ & $2.3 \times 10^{2}$ & $1.4 \times 10^{2} \pm 5.9 \times 10$ \\
\hline Chicken panée & 2 & 8 & $3.6 \times 10$ & $1.5 \times 10^{2}$ & $9.3 \times 10 \pm 5.7 \times 10$ \\
\hline Chicken frankfurter & 2 & 8 & $1.9 \times 10$ & $1.1 \times 10^{2}$ & $6.4 \times 10 \pm 4.5 \times 10$ \\
\hline Total & 16 & 12.8 & - & - & - \\
\hline
\end{tabular}


Incidence of some anaerobic bacteria isolated from chicken meat products with special reference to Clostridium perfringens

Table (5): Incidence of Lecithinase positive strains of $C$. perfringens in the examined chicken meat product samples $(\mathrm{n}=25)$.

\begin{tabular}{|c|c|c|c|c|c|c|}
\hline \multirow{2}{*}{ samples } & \multicolumn{2}{|c|}{ Number of isolates } & \multicolumn{2}{|c|}{ Lecithinase positive } & \multicolumn{2}{|c|}{ Lecithinase negative } \\
\hline & NO. & $\%$ & NO. & $\%$ & NO. & $\%$ \\
\hline \multicolumn{7}{|c|}{ Raw chicken meat } \\
\hline Chicken breast & 6 & 24 & 2 & 33.3 & 4 & 66.6 \\
\hline Chicken thigh & 8 & 32 & 3 & 37.5 & 6 & 62.5 \\
\hline \multicolumn{7}{|c|}{ Half cooked chicken meat products } \\
\hline Chicken nuggets & 5 & 20 & 1 & 20 & 4 & 80 \\
\hline Chicken panée & 4 & 16 & 2 & 50 & 2 & 50 \\
\hline Chicken frankfurter & 4 & 16 & 1 & 25 & 3 & 75 \\
\hline Total & 27 & 21.6 & 9 & 33.3 & 18 & 66.6 \\
\hline
\end{tabular}

Table (6): serotyping of toxigenic Clostridium perfringens strains isolated from chicken meat product samples.

\begin{tabular}{|c|c|c|c|c|c|c|c|c|c|}
\hline \multirow{3}{*}{$\begin{array}{c}\text { Poultry meat } \\
\text { product samples }\end{array}$} & \multirow{3}{*}{$\begin{array}{l}\text { No. of } \\
\text { toxigenic } \\
\text { isolates }\end{array}$} & \multicolumn{8}{|c|}{ Types of isolates } \\
\hline & & \multicolumn{2}{|c|}{$\mathrm{A}$} & \multicolumn{2}{|c|}{ B } & \multicolumn{2}{|c|}{$\mathrm{C}$} & \multicolumn{2}{|c|}{$\mathrm{D}$} \\
\hline & & No. & $\%$ & No. & $\%$ & No. & $\%$ & No. & $\%$ \\
\hline \multicolumn{10}{|c|}{ Raw chicken meat } \\
\hline Chicken breast & 2 & 2 & 100 & 0 & 0 & 0 & 0 & 0 & 0 \\
\hline Chicken thigh & 3 & 2 & 66.6 & 0 & 0 & 0 & 0 & 1 & 33.3 \\
\hline \multicolumn{10}{|c|}{ Half cooked chicken meat products } \\
\hline Chicken nuggets & 1 & 1 & 100 & 0 & 0 & 0 & 0 & 0 & 0 \\
\hline Chicken panée & 2 & 2 & 100 & 0 & 0 & 0 & 0 & 0 & 0 \\
\hline Chicken frankfurter & 1 & 1 & 100 & 0 & 0 & 0 & 0 & 0 & 0 \\
\hline Total & 9 & 8 & $6.4^{*}$ & 0 & 0 & 0 & 0 & 1 & $0.8^{*}$ \\
\hline
\end{tabular}

* incidence of toxigenic strains in relation to total number of samples (125). 
Table (7): Incidence of heat resistant strains of $C$. perfringens isolates and its typing ( $\mathrm{n}=25)$.

\begin{tabular}{ccccccccccc}
\hline & \multicolumn{3}{c}{$\begin{array}{c}\text { Heat resistant positive } \\
\text { Samples }\end{array}$} & \multicolumn{8}{c}{ Typing of heat resistant C. perfringens } \\
isolates
\end{tabular}




\section{DISCUSSION}

The modern revolutionary poultry industry made poultry meat available for large population of consumers, and considered a major source of animal protein supplement especially due to its nutritional, sensory, economic and consumer profitability characteristics. However, poultry meat may harbor different types of pathogenic microorganisms during different processing procedures. Anaerobic spore formers are one of implicated microorganisms in worldwide foodborne outbreaks especially C. perfringens which associated mainly to consumption of meat, poultry and its products.

Results illustrated in table (1) were in a great reliable to (Nabil et al., 2014) $\left(4.8 \times 10^{2} \mathrm{cfu} / \mathrm{g}\right.$ in frankfurter); and (Sobhy, 2016) $\left(5.6 \times 10^{3}\right.$ to $5.1 \times 10^{4} \mathrm{cfu} / \mathrm{g}$, with incidence of $40-66 \%$ in chicken meat). While recorded higher results than (Zakaria, 2005) results who reported the total anaerobic counts of examined chicken meat products were ranged from $2.3 \times 10^{2}-5.5 \times 10^{3} \mathrm{cfu} / \mathrm{g}$.

Microscopical and biochemical identification of other than C. perfringens isolates as illustrated in table (2) were recorded to be found in different examined chicken meat products as reported by (Zakaria, 2005) who detected C. sporogenes, C. butyricum, C. subterminalis in different examined chicken meat products; and (Sathish and Swaminathan, 2009) who isolated C. bifermentans from $40 \%$ of examined chicken meat samples.

Clostridium perfringens is considered as foodborne pathogen of public health importance due to its ability to produce many lethal and enterotoxins. C. perfringens food poisoning may occur after consumption of improper hot held cooked food or slowly cooled after preparation; where some heat resistant spores (100OC for more than $1 \mathrm{~h}$ ) can survive, subsequently spore germination and rapid multiplication leading to food poisoning (Simjee and poole, 2007).

Table (3\&4) results were in agree with (Edris et al., 1992) who reported the highest $C$. perfringens prevalence in examined thigh samples followed by breast and frankfurter samples; (Zakaria, 2005) who recorded isolation of $C$. perfringens (vegetative and spore form) in examined chicken breast, thigh and frankfurter samples in prevalence of 25, 35, 10\%, respectively; (Emara, 2014) (30\% in examined fillet); (Nabil et al., 2014) $(13.3 \%$ in frankfurter with count of 3.6x102 cfu/g); (Kamal, 2017) who detected C. perfringens (vegetative and spore form) in count of $1.5 \times 104$ and $1.58 \times 102 \mathrm{cfu} / \mathrm{g}$, respectively in chicken meat. On contrast, results were lower than that reported by (Salah El-din et al., 2015) who detected C. perfringens in $79.6 \%$ of examined samples; while, higher than those reported by (Thangamani and Subramanian, 2012) who detected C. perfringens in $3.81 \%$ of examined samples. Moreover, reported results were disagreed with (Hashem, 2015) and (Ibrahim-Hemmat et al., 2015) who failed to detect C. perfringens in any examined chicken meat sample.

Differences may be attributed to difference in effectiveness of hygienic measures during processing practices, handling from production to consumption; high contamination of raw materials; addition of additives, spices 
and preservatives as well as the conditions occurred before and after slaughtering of the birds affect the bacterial load in these products.

Only C. perfringens type A produces the alpha-toxin and phospholipase C (PLC). This exotoxin has the distinction of being the first bacterial toxin to which an enzymatic activity, lecithinase enzyme; inoculation of C. perfringens type A with lecithinase activity on egg yolk agar produce an opalescent change around the colonies due to enzymatic action of lecithin in the medium. Those producing a lipase cause a pearly layer or iridescent film that can cover the colonies and in some cases, extend into the surrounding agar (Markey et al., 2013).

Lecithinase activity of C. perfringens isolates as tabulated in table (5) were nearly similar to (Sobhy, 2016) who reported $27.2 \%$ of C. perfringens isolates were lecithinase positive, while (Kamal, 2017) reported higher results where $66.6 \%$ of examined isolates were lecithinase positive.

Prevalence and typing of toxigenic C. perfringens results as typed in tables (6) were in agree with (Torky and Hassan, 2014) who recorded that traditional typing of $C$. perfringens isolates revealed $8(6.4 \%)$ of type $\mathrm{A}$ and $1(0.8 \%)$ of type $\mathrm{D}$, while failed to detect either type B or C.

Clostridium perfringens type (A) is usually contributed in worldwide food poisoning outbreaks. Symptoms appear within 6 to 24 hours after consumption of contaminated food characterized by acute abdominal cramps, watery diarrhea, nausea, and rarely fever with vomiting especially in children and elderly persons. Furthermore, chicken dishes are commonly involved in such outbreaks particularly when prepared and held long period before consumption, so the hot cooking of such food is usually presumably inadequate to destroy the heat resistance endospores leading to release of enterotoxin by $\mathrm{C}$. perfringens cells undergoing sporulation in the lower part of gastrointestinal tract (Mossel et al., 1995); (McClane and Rood, 2001). However, C. perfringens type A common contribution in food poisoning, type (D) has been implicated in food poisoning cases which produce symptoms resembled that produced by other food poisoning pathogens as recorded by (Kohn and Warrack, 1955).

Table (7) discussed number and prevalence of heat resistant C. perfringens spores isolates; results were in agree with (Kudaka et al., 2005) who reported that food poisoning $\mathrm{C}$. perfringens spores differed from those vegetative cells in respect to its heat resistance; where they can survive cooking at high temperature (100OC for $>2 \mathrm{~h}$ ); while lower than (Zakaria, 2005) who notified heat resistant C. perfringens in $15 \%$ of examined isolates, where C. perfringens type A was predominant $(66.6 \%)$ followed by type D $(33.3 \%)$.

Poultry meat and meat products may be considered as a major source of anaerobic bacteria especially C. perfringens, which may get contamination through many different ways; raw poultry meat samples exhibited higher C. perfringens contamination levels starts with thigh sample, followed by breast, nuggets, panée and frankfurter samples, respectively. High counts of anaerobic spore forming bacteria especially C. perfringens may render these types of 
Incidence of some anaerobic bacteria isolated from chicken meat products with special reference to Clostridium perfringens

food of inferior quality or even become harmful for the consumers, so restrict hygienic measures should be applied during different stages of chicken processing till consumption.

\section{REFERENCES}

American Public Health Association (APHA), 1992. "Compendium of methods for the microbiological examination of foods. 3rd Ed. APHA Technical Committee on Microbiological Methods for Foods. Washington, D. C. USA.

Bullen, J.J. 1952. "Clostridium welchii type $D$ in the alimentary tract of normal sheep". J. Path. Bact., 64:201- 210.

Carter, G.R.; Cole, J.R. 1990. "Diagnostic procedures in veterinary bacteriology and mycology". 5th Ed., Academic Press, Harcourt, Boace. J., New York, Boston, Tokyo, Toronto.

Cato, E.P.; George, W.L.; Finegold, S.M. 1986. "Bergeys manual of systematic bacteriology, Vol.2. Williams and Wilkins, Baltimore, USA.

Cruickshank, R.; Duguid, J.P.; Marmion, B.P.; Swain, R.H. 1975. "Medical Microbiology". $2^{\text {nd }}$ Ed., Vol.2. The Practice of Medical microbiology, Churchill Living Stone Edinburgh.

Edris, A. M.; Abdel Rahman, M.; Mousa, M.M. 1992. "Microbial evaluation of some related cut-up chicken and poultry meat product". Benha Vet. Med. J., 3(1): 154-165.

Egyptian Standard Specifications (EOS) 2005. No. 1651 for chilled raw poultry and rabbit meat, No. 3492 for chicken frankfurter, and No. 3493 for heat treated poultry meat products.

El-Bassuony, R.A. 2008. "Bacterial evaluation of frozen poultry and some poultry products in Luxor City". J.
Egypt. Vet. Med. Assoc., 68 (4): 295307.

Ellner, P.D. 1956. "A medium promoting rapid quantitative sporulation in Clostridium perfringens". J. Bact., 71: 495-596.

Emara, M.S. 2014. "Anaerobic and aerobic microorganisms in human food". M. V. Sc. Thesis, Fac. Vet. Med., Cairo Univ., Egypt.

Feldman, D.; Ganon, J.; Haffman, R.; Simpson, J. 2003. "The solution for data analysis and presentation graphics. $2^{\text {nd }}$ Ed., Abacus Lancripts, Inc., Berkeley, USA.

Geornaras, I.A.; De Jesus, E.V.; Von Holy, A. 1995. "Microbiological survey of a South African poultry processing plant". J. Basic Microbiol, 35: 73-82.

Hashem, H.M. 2015. "Bacteriological criteria of dressed poultry with special reference to some microbial decontaminators". M. V. Sc. Theis, Fac. Vet. Med., Benha Univ., Egypt.

Hussein, A.Z. 1997. "The physical condition of cattle before slaughtering and its relationship to probable isolation of Clostridium perfringens from carcasses".

Ibrahim-Hemmat, M.; Amin-Reham, A.; ElShater, M.A.; Hafez-Salwa, M. 2015. "Bacteriological evaluation of freshly slaughtered chicken carcasses". BVMJ, 28(2): 74-82.

ISO "International Standard Organization" 2004. "Microbiology of food and animal feeding stuffs-horizantal method for the enumeration of Clostridium perfringenscolony count technique". Ref. No. ISO 7937:2004.

Kamal, A. 2017. "Clostridium perfringens in meat and chicken received in University hostel". M. V. Sc. Thesis, Fac. Vet. Med., Benha Univ., Egypt.

Kessel, A.S.; Gillespie, I.A.; O' Brien, S.J.; Adak, G.K.; Humphrey, T.J.; Ward, 
L.R. 2001. "General outbreaks of infectious intestinal disease linked with poultry, England and wales, 19921999". Common Dis. Public Health, 4 (2):171-177.

Kohn, J.; Warrack, G.H. 1955. "Recovery of Clostridium perfringens type $D$ from man". Lancet, 1: 385-390.

Kudaka, J; Horikawa, K; Uryu, K; Matsuyuki, S; Ogata, K; Kawano, K; Yamaguchi, Y; Yamasaki, S; Watanabe, H.; Iwanaga, M. 2005. "Symptoms of foodborne diseases and gastroenteritis in Kyushu, Japan". Kansenshogaku Zasshi, 79: 864-870.

MacFaddine, F. 1980. "Biochemical tests for identification of medical bacteria". 2nd Ed., Williams and Wilkins, Baltimore, USA.

Markey, B.K.; Leonard, F.C.; Archambault, M.; Cullinane, A.; Maguire, D. 2013. "Clinical Veterinary Microbiology". $2^{\text {nd }}$ Ed., Mosby Elsevier Press, London, New York, Oxford; p. 217-220.

McClane, B.A.; Rood, J.I. 2001. "Clostridial toxins involved in human enteric and histotoxic infection". In: Clostridia: Biotechnology and Medical Applications. Bahl H, Dürre P. (Eds.), Wiley-VHC Weinheim, p. 169-220.

Mossel, T.A; Corry, J.L.; Struijk, C.B.; Beird, R.N. 1995. "Essentials of microbiology of foods". John, New York.

Nabil, M.E.; Edris, A.M.; Shaltout, F.A.; Zakaria, I.M. 2014. "Effect of some preservatives on bacterial load of some poultry meat products". Benha Vet. Med. J., 26(1): 94-103.

Oakley, A.; Warrack, S. 1953. Routine typing of Clostridium welchii”.J. Hyg. Gamb., 51:102- 107.

Roberts, D; Hooper, W.; Greenwood, M. 1995. "Practical food microbiology". Puteler and Tanar, London.

Salah-Eldin, A.H.; Fawzy, E.H.; Aboelmagd, B.A.; Ragab, E.A.;
Bedawy, S. 2015. "Clinical and laboratory studies on chicken isolates of Clostridium Perfringens in El-Behera, Egypt". J. World's Poult. Res., 5(2): 2128.

Santos, G.; Mirna, A.; Marivael, G.; Nerma, H. 2002. "Inhibition of growth enterotoxin production, and spore formation of $C$. perfringens by extracts of medicine plants". J. Food Prot., 65(10): 1667-1669.

Sathish, S.; Swaminathan, K. 2009. "Genetic diversity among toxigenic clostridia isolated from soil, water, meat and associated polluted sites in South India". Indian J. Med. Microbiol., 27(4): 311320.

Shedeed, N.A. 1999. "Evaluation of microwave cooking of chicken meat". M. Sc. Thesis Fac. of Agric., Cairo University.

Simjee, S.; Poole, T.L. 2007. "Foodborne diseases". Human Press, Totowa, New Jersy.

Smith, W.P.; Holdeman, L. 1968. "The Pathogenic Anaerobic Bacteria". $1^{\text {st }}$ Ed. Pp. 201-255.

Sobhy, A.E. 2016. "Microbial status of meat and chicken received to university hostel". M. V. Sc. Thesis, Fac. Vet. Med., Benha Univ., Egypt.

Sterne, M.; Batty, I. 1975. Pathogenic Clostridia. Buthogenic, London, Baston.

Stevenson, K.E.; Bernard, D.T. 1995. "Establishing hazard analysis critical control point programs". A work shop manual, $2^{\text {nd }}$ Ed., p. 4-15, 4-20. The Food Processors Institute, Washington. D. C.

Thangamani, A.; Subramanian, S. 2012. "Prevalence of Clostridium perfringens in the chicken meat rendered at retail outlets of Namakkal, Tamilnadu". Journal of Advanced Veterinary Research, 2: 157-159.

Torky, H.A.; Hassan, M.A. 2014. "Sequence analysis of alpha toxin produced by $C$. perfringens isolated from different 
Incidence of some anaerobic bacteria isolated from chicken meat products with special reference to Clostridium perfringens

sources". Nature and Science, 12(1): 5561.

Varnam, P.; Evans, M. 1991. "Food borne pathogens". An illustrated text book. Wolf publishing Ltd., New York, App., 101-108.

Voidarou, C.; Vassos, D.; Rozos, G.; Alexopoulos, A.; Plessas, A.; Tsinas, A.; Skoufou, M.; Stavropoulou, E.; Bezirtzoglou, E. 2011. "Microbial challenges of poultry meat production". Anaerobe, 17: 341-343.

Weiss, D.; Strong, H. 1967. "Some properties of heat resistant and heat sensitive strains of Clostridium perfringens". J. Bacterial., 93:21.

Willis, A.T. 1977. "Anaerobic Bacteriology Practice". $3^{\text {rd }}$ Ed. Butter Worths, London.

Zakaria, I.M. 2005. "Anaerobic bacteria in chicken meat products". M.V.Sc. Thesis, Fac. Vet. Med., Zagazig University, Benha branch.

Zhang, L.; Davis, M.A.; Conner, D.E. 2001. "Poultry-borne pathogens: plant consideration". Poultry Meat Processing, ch. 9. ISBN 0-8493-0120-3, CRC Press LLC, New York, USA. 